\title{
Evaluation of African marigold (Tagetes erecta L.) Varieties for Morphological and Biochemical Characters under West Bengal Condition
}

\author{
Amit Lohar", Jayoti majumder, Aritra Sarkar and Bishal Rai \\ Department of Floriculture and Landscaping, Faculty of Horticulture, Bidhan Chandra Krishi \\ Viswavidyalaya, Mohanpur-741252, West Bengal, India \\ *Corresponding author
}

\section{A B S T R A C T}

\section{Keywords}

Morphological, African marigold, Antioxidant activity

Article Info

Accepted:

04 September 2018

Available Online:

10 October 2018
A field experiment was conducted to study the morphological and biochemical characters of African marigold as influenced by different varieties under West Bengal conditions. With five different varieties namely, Pusa Narangi Gainda, Seracole, Inca Orange, Sun Set Orange and Cracker Jack were taken as experimental material. The results revealed that, the earliest days to first flower was recorded in Inca orange (51.25), maximum number of flowers plant ${ }^{-1}$ in Seracole (67.3) yield of flowers plant ${ }^{-1}$ in Seracole $(449.77 \mathrm{~g}$ ), fresh weight of flower ${ }^{-1}$ in Inca orange $(7.80 \mathrm{~g})$, weight of petals plant ${ }^{-1}$ in Seracole $(366.90 \mathrm{~g})$, Diameter of fully opened flower in Inca orange $(9.23 \mathrm{~cm})$. Whereas, biochemical character of African marigold to quantify the active biological compounds in (Tagetes erecta L.) flowers of different varieties. Biochemical characters analyzed were total carotenoids, total phenols, total flavonoid and antioxidant activity. The different varieties of marigold also showed marked variations in total carotenoids, total phenols, total flavonoid and antioxidant activity. In Pusa Narangi Gainda was maximum antioxidant activity recorded and minimum was achieved in Cracker Jack.

\section{Introduction}

In India, the total area under marigold cultivation is 42.88 thousand hectares with production of 501.87 thousand tonnes (Anon, 2015). West Bengal ranks $2^{\text {nd }}$ in area $\left(6.17^{\prime} 000 \mathrm{ha}\right)$ and $3^{\text {rd }}$ in marigold production (381.98 Thousand MT) in the country (NBH DATA2012) West Bengal with wide agro climatic diversity is the leading state for the commercial cultivation of loose flowers. East Midnapore, Howrah, Hooghly, 24-Paraganas, Burdwan and Nadia are the main districts growing important commercial flowers on large scale both as cut and loose flowers (Razzaq et al., 2014). Marigold has also been used as medicinal plant as it has been reported to have therapeutic properties, such as antimutagenicity, anti-inflammatory, antitumourogenic, antiviral and immunostimulating effects (Gonzalez de Mejia et al., 1997; Hamburger et al., 2003). The pharmacological activities of marigold are related to the content of several classes of secondary metabolites such as flavonoids, sterols, carotenoids, tannins, saponins, triterpene alcohols, polysaccharides, a bitter principle, mucilage and resin (Jacobs et al., 
1994; Piccagliy et al., 1998). African marigold (Tagetes erecta L.) belongs to the family Asteraceae and is one of the most important commercially exploited flower crops. Genus Tagetes consists of 33 species, of which Tagetes erecta $\mathrm{L}$. is commonly grown for their exquisite blooms. Marigold is native of Central and South America, especially Mexico. The chromosome number is $\mathrm{x}=12$ and $2 \mathrm{n}=24$. The other species introduced in India are Tagetes signata Linn. Tagetes minuta Linn, Tagetes lucida and Tagetes tenuifolia. Marigold flowers are used as food colorant and ingredient in cooking, they may be used as the fresh petals or as a dried powder, which can be made into tea, spice and medicine (tinctures, ointments and creams) An extract of marigold flower has been used commercially as an additive to poultry feed to improve the pigmentation of the bird's fat, skin and egg yolk (Bailey and Chen, 1989) Marigold flower is one of the richest sources of natural carotenoids.

It has gained popularity on account of carotenoids production. Carotenoids are organic pigments which are naturally occurring in the chloroplast and chromoplats of plants and some photosynthetic organism like algae. Carotenoids are responsible for the yellow, orange and red pigment in a large variety of plants.

Therefore, the aim of this study was to investigate the influence of these biochemical characters on marigold petals from five Indian varieties viz. Pusa Narangi Gainda, Seracole, Inca Orange, Sun Set Orange and Cracker Jack with respect to color, bioactive compounds like total phenolic compounds and $\beta$-carotene. The antioxidant properties of all treated samples were also evaluated. Present study was carried out with the objective morphological and biochemical characters of African marigold under West Bengal condition.

\section{Materials and Methods}

The present investigation was carried out at Horticultural Research Farm, (Mandouri) and Department of Floriculture and landscaping, Faculty of Horticulture, Bidhan Chandra Krishi Viswavidyalaya, Mohanpur, Nadia, and West Bengal, during the year 2016-17. The experiment was planned out in Randomized Block Design with five treatments replicated forth time. The experiment comprised with five varieties viz., $\mathrm{V}_{1^{-}}$Pusa Narangi Gainda, $\mathrm{V}_{2^{-}}$Seracole, $\mathrm{V}_{3^{-}}$Inca Orange, $\mathrm{V}_{4^{-}}$Sun Set Orange and $\mathrm{V}_{5}$ - Cracker Jack.

Raised nursery bed was drenched with malathion dust. The nursery beds were watered daily twice for first 10 days and daily once for the remaining period. Hand weeding was done twice when the seedlings were 15 days and 25 days old Seeds were treated with fungicide for healthy growth of seedlings and sown in lines at $10 \mathrm{~cm}$ spacing and $2-3 \mathrm{~cm}$ deep in the soil. Seeds were then gently covered with the soil. The seedlings were ready for transplanting at 30 days after sowing. The land was brought to a fine tilth by repeated ploughing and harrowing. Thirty days old healthy and uniformly grown seedlings were used for transplanting with a spacing of $45 \mathrm{~cm} \times 30 \mathrm{~cm}$ in the experimental field on 15th October 2016. The recommended dose of fertilizer (100: 50: 25 $\mathrm{kg} \mathrm{NPK} \mathrm{ha}{ }^{-1}$ ) was applied to all the plots in the form of urea, Single Super Phosphate and Muriate of Potash. Out of this, full dose of $\mathrm{P}_{2} \mathrm{O}_{5}$ and $\mathrm{K}_{2} \mathrm{O}$ and $1 / 2$ dose of Nitrogen was applied at the time of transplanting. The remaining dose of nitrogen was applied in two split doses, first dose was given at 15 days and second dose was given at 30 days after transplanting.

Observations were recorded on important growth parameters such as (i) Days to first flower, (ii) Number of flowers plant ${ }^{-1}$, (iii) Yield of flowers plant ${ }^{-1}(\mathrm{~g})$, (iv) Fresh weight 
of flower ${ }^{-1}(\mathrm{~g})$, (v) weight of petals plant ${ }^{-1}(\mathrm{~g})$, (vi) Diameter of fully opened flower $(\mathrm{cm})$ and (vii) biochemical characters were recorded after harvesting and collected data were statistically analyzed by Completely Randomized Design the significance on various parameters was determined using analysis of variance (ANOVA).

\section{Extraction of carotenoid pigments}

$5 \mathrm{~g}$ of sample was ground in a mortar and pestle with acetone. The extract was decanted into a conical flask. Extraction was continued till the entire pigment were extracted and the residue became colourless. The extract was transferred to a separating funnel. Then 1015 mlof petroleum ether and water containing 5percent anhydrous sodium sulphate were added. Extraction of acetone phase was repeated with small volume of petroleum ether until no more colours was extracted. A small amount of anhydrous sodium sulphate was added to absorb the excess water and volume was made up with eluent (3\% acetone in petroleum ether). The colour was measured at $452 \mathrm{~nm}$ using eluent as blank in spectrophotometer. Results were expressed as $\mu \mathrm{g} / 100 \mathrm{~g}$ of material (Ranganna, 1997).

\section{Calculation}

Total Carotenoids $(\mathrm{mg} / 100 \mathrm{~g}$ sample $)=$

3.857 $\times$ optical density $\times$ volume made up $\times$ dilution $\times 100$

$1000 \times$ weight of sample

\section{Total Phenolics Content (TPC)}

The amount of total phenolic content (TPC) was investigated using the Folin-Ciocalteau assay (Djeridane et al., 2006) briefly $5 \mathrm{~g}$ sample was extracted with $50 \mathrm{ml} 80 \%$ methanol. The aliquot $(1 \mathrm{ml})$ were taken in the test tubes and were added with $2.9 \mathrm{ml}$ of Folin and Ciocalteau's Phenol Reagent (1N). To that, $0.5 \mathrm{ml}$ of distilled water was added and all the tubes were shaken well. Then, $2 \mathrm{ml}$ of sodium carbonate $(20 \%)$ solution was added to all the tubes and kept for incubation at room temperature for 30 minutes. The colour developed was read in spectrophotometer at $760 \mathrm{~nm}$ wavelength. Standard curve was drawn using gallic acid as standard. Different concentrations of gallic acid were prepared and O.D was read at $760 \mathrm{~nm}$ wavelength. The concentration of samples was calculated based on the standard curve.

\section{Calculation}

O.D x standard curve factor $\mathrm{x}$ volume made up x Dilution Mg gallic acid =

Equivalence per gram Aliquot taken x weight of sample

\section{Total flavonoid content}

The colorimetric method described by $\mathrm{Abu}$ Bakar et al., (2009) was used to determine total flavonoid content. $0.3 \mathrm{ml}$ of the extract was mixed with $2.1 \mathrm{ml}$ of absolute alcohol in a test tube. Then, $0.3 \mathrm{ml}$ of $5 \% \mathrm{NaNO}_{2}$ solution was added. After $5 \mathrm{~min}, 0.3 \mathrm{ml}$ of $10 \% \mathrm{AlCl}_{3}$ solution was added to it followed by $3.4 \mathrm{ml}$ of $4 \mathrm{~N} \mathrm{NaOH}$ after $5 \mathrm{~min}$. The mixture was vortexed and incubated at room temperature. The absorbance was read at $510 \mathrm{~nm}$ after 5-10 minutes of incubation using spectrophoto meter. Standard curve was drawn using Rutin as standard. Different concentrations of rutin were prepared and O.D was read at $510 \mathrm{~nm}$. The concentration of samples was calculated based on the standard curve.

\section{Calculation}

O.D x Factor x volume made up $\mathrm{Mg}$ Rutin equivalence $=$

Per gram Aliquot taken $\mathrm{x}$ weight of sample 


\section{DPPH free radical scavenging activity}

The DPPH assay method is based on the reduction of DPPH, a stable free radical. The antioxidant activity of the extracts was determined using DPPH assay described by Braca et al., (2001). Aqueous extract $0.1 \mathrm{ml}$ was added to $3.9 \mathrm{ml}$ of $0.0025 \mathrm{M}$ DPPH (2, 2Diphenyl-1- picrylhydrazyl) in methanol (70\%). The mixture was shaken and allowed to stand for $30 \mathrm{~min}$. in dark at room temperature. Absorbance was read at $517 \mathrm{~nm}$ using spectrophotometer. The per cent inhibition of activity was calculated by the formula

Percent inhibition $(\%)=[($ Ao-Ae $) / A o] \times 100$

$($ Ao $=$ absorbance without extract; Ae $=$ absorbance with extract).

\section{Results and Discussion}

\section{Morphological parameters of marigold petals}

Data presented in Table 1 revealed that there is a significant variation and the days for first flowering were observed among five varieties ranged from 51.25 to 63.05 days. The variety $\mathrm{V}$ 3'Inca orange' required significantly minimum number of days for first flowering (51.25 days).Whereas, variety $\mathrm{V}_{4}$ 'Sun set orange' recorded maximum number of days required for first flowering (63.05 days). The time required for days taken to first flower opening is an important genotypic character in marigold that might be primarily governed by the genetic makeup of the genotypes. The results observed were in line with earlier findings of Beniwal and Dahiya (2012).

Flower diameter was significantly maximum with varieties Inca orange $(9.23 \mathrm{~cm})$ followed by Pusa Narangi Gainda $(5.90 \mathrm{~cm})$ and Seracole $(5.63 \mathrm{~cm})$ while minimum flower diameter was recorded with Cracker Jack $(5.40 \mathrm{~cm})$ and Sun set orange $(5.01 \mathrm{~cm})$ Variation in flower diameter might be due to the genetic makeup of the varieties and their interaction with prevailing genotype and environment. Similar results were observed by Narsude et al., (2010), Deepa et al., (2016) in marigold.

Significant differences were found among the varieties evaluated with respect to number of flowers per plant. The data range was found between 19.4 to 67.3 Variety $V_{2}$ 'Seracole' was recorded maximum number of flowers per plant (67.3) followed by $\mathrm{V}_{5}$ 'Cracker Jack' (57.3), the minimum number of flowers per plant was observed in variety $\mathrm{V}_{3}$ 'Inca orange (19.4). The increased number of flowers plant ${ }^{1}$ might be due to cell elongation and rapid cell stimulation. Similar results were also noticed by Choudhary et al., (2014), Bharathi and Jawaharlal (2014) in African marigold.

Significantly maximum yield of flowers plant $^{-1}(449.77 \mathrm{~g})$ was recorded in $\mathrm{V}_{2}$ 'Seracole' However, significantly minimum yield of flowers plant $^{-1}(164.10 \mathrm{~g})$ was recorded in ' $\mathrm{V}_{3}$ ' Inca orange. These results might be due to variation in production of flower yield. Similar results were also reported by Deepa et al., (2016)

' $\mathrm{V}_{3}$ ' Inca orange produced significantly maximum weight of flower $(7.80 \mathrm{~g})$. Whereas, significantly minimum weight of flower (4.29 g) was recorded in ' $V_{5}$ ' Cracker Jack. The variation in weight of flower might be due to the variation in size, length of flower and number of petals flower ${ }^{-1}$. The results are in close agreement with the findings of Narsude et al., (2010), Deepa et al., (2016) in marigold.

' $\mathrm{V}_{2}$ ' Seracole recorded maximum weight of petals plant ${ }^{-1}(366.90 \mathrm{~g})$. However, minimum weight of petals plant $^{-1}(116.19 \mathrm{~g})$ was recorded in Inca orange. 
Table.1 Morphological growth and flower yield of African marigold during winter under west Bengal conditions 2016-17

\begin{tabular}{|c|c|c|c|c|c|c|}
\hline Varieties & Days to first flower & $\begin{array}{l}\text { Flower diameter } \\
(\mathrm{cm})\end{array}$ & No. of flowers plant ${ }^{-1}$ & $\begin{array}{l}\text { Yield of flower } \\
\text { plant }^{-1}(\mathrm{~g})\end{array}$ & $\begin{array}{l}\text { Fresh weight of } \\
\text { flower }^{-1}(\mathrm{~g})\end{array}$ & $\begin{array}{l}\text { Weight of petals } \\
\text { plant }^{-1}(\mathrm{~g})\end{array}$ \\
\hline $\mathbf{V}_{1}$ & 61.55 & 5.90 & 35.7 & 184.22 & 6.81 & 126.92 \\
\hline$\overline{V_{2}}$ & 55.35 & 5.63 & 67.3 & 449.77 & 6.59 & 366.90 \\
\hline$\overline{\mathbf{V}_{3}}$ & 51.25 & 9.23 & 19.4 & 164.10 & 7.80 & 116.19 \\
\hline $\mathbf{V}_{4}$ & 63.05 & 5.01 & 51.6 & 221.37 & 5.06 & 139.51 \\
\hline$\overline{V_{5}}$ & 56.45 & 5.40 & 57.3 & 225.92 & 4.29 & 162.95 \\
\hline S. $\operatorname{Em}( \pm)$ & 1.87 & 0.09 & 0.66 & 1.70 & 0.06 & 1.00 \\
\hline C.D. at 5\% & 5.81 & 0.28 & 2.04 & 5.30 & 0.17 & 3.11 \\
\hline
\end{tabular}

$\mathrm{V}_{1}$-Pusa Narangi Gainda, $\mathrm{V}_{2^{-}}$Seracole, $\mathrm{V}_{3}$-Inca orange, $\mathrm{V}_{4}$ - Sun set orange, $\mathrm{V}_{5^{-}}$Cracker Jack

Table.2 Biochemical Characters of African marigold fresh petals during winter under West Bengal conditions 2016-17

\begin{tabular}{|c|c|c|c|c|}
\hline Varieties & $\begin{array}{l}\text { Total carotenoids } \\
\text { (mg/100g) }\end{array}$ & $\begin{array}{l}\text { Total phenol } \\
\text { (mg GAE/g) }\end{array}$ & $\begin{array}{l}\text { Total flavonoid } \\
\text { content } \\
\text { (mg RE/g) }\end{array}$ & $\begin{array}{l}\text { Anti-oxidant activity } \\
(\%)\end{array}$ \\
\hline $\mathbf{V}_{1}$ & 100.53 & 102.43 & 34.43 & 89.87 \\
\hline$\overline{V_{2}}$ & 83.37 & 98.70 & 29.63 & 86.17 \\
\hline$\overline{V_{3}}$ & 75.47 & 94.57 & 28.43 & 64.20 \\
\hline $\mathrm{V}_{4}$ & 66.27 & 82.33 & 23.77 & 60.33 \\
\hline$\overline{V_{5}}$ & 56.07 & 72.77 & 24.67 & 53.60 \\
\hline S. Em ( \pm ) & 0.84 & 0.84 & 0.74 & 0.77 \\
\hline C. D. at $5 \%$ & 2.68 & 2.69 & 2.37 & 2.48 \\
\hline
\end{tabular}

$\mathrm{V}_{1}$-Pusa Narangi Gainda, $\mathrm{V}_{2}$ - Seracole, $\mathrm{V}_{3}$-Inca orange, $\mathrm{V}_{4}$ - Sun set orange, $\mathrm{V}_{5^{-}}$Cracker Jack 
This might be due to variation in their genetic factor. Poornachandragowda et al., (2016) in marigold. Maximum carotene content of $(88.22 \mathrm{mg} / 100 \mathrm{~g})$ was obtained in ' $\mathrm{V}_{1}$ ' Pusa Narangi Gainda and minimum number of carotene content was recorded in ' $\mathrm{V}_{3}$ ' Inca orange (43.13 mg/100g) The variety Pusa narangi gainda performed better than all the other African marigold may be due to its genetic makeup and its better adaptability to the prevailing environmental condition.

\section{Biochemical properties of marigold petals}

The biochemicals were analyzed for total carotenoids $(\mathrm{mg} / 100 \mathrm{~g})$, total Phenol content (mg GAE/g), total flavonoid Content and antioxidant activity (\%) with five different varieties. The data are presented in Table 2.

The total carotenoids content varied significantly due to the influence of different genotypes. Significantly maximum carotene content $(100.53 \mathrm{~g})$ was recorded in the treatment $\mathrm{V}_{1}$ which was significantly superior to all other treatments including check variety followed by $\mathrm{V}_{2}(83.37 \mathrm{~g})$. However, the minimum carotene content was recorded in $\mathrm{V}_{5}(56.07 \mathrm{~g})$. The carotene content variation may be due to colour of flower and also due to different genetic makeup of genotypes (Naik, 2003). The findings are in conformity with the research finding of Rao et al., (2005) and Iftikhar et al., (2011) in African marigold.

Total phenolic content was maximum (102.43 $\mathrm{mg} \mathrm{GAE} / \mathrm{g})$ in $\mathrm{V}_{1}$ and minimum in $\mathrm{V}_{5}(72.77$ mg GAE/g) which was different when compared to other treatments. Phenols are very important plant constituents because of their scavenging ability on free radicals due to their hydroxyl groups. Therefore, the phenolic content of plants may contribute directly to their antioxidant action. Similar results were also reported by Ahluwalia et al., (2014). The highest flavonoid contents were found in the cultivar $\mathrm{V}_{1}$ (34.43) $\mathrm{mg} \mathrm{RE} / \mathrm{g}$ and the contents were lowest in $\mathrm{V}_{5}$ (24.67) $\mathrm{mg} \mathrm{RE} / \mathrm{g}$. Previous research has observed large variations in the total phenolic and flavonoid contents between five different species of marigold. Our results showed that wide variations (almost fourfold) in the content of the two groups of compounds also existed among the different marigold cultivars of the same species. Antioxidant activity also showed a significantly decreasing trend in different varieties. The highest antioxidant activity $89.87 \%$ was recorded at $\mathrm{V}_{1}$ and a closer view of data exhibit that in $\mathrm{V}_{2} 86.17 \%$ and minimum in $\mathrm{V}_{5} 53.60 \%$.

From the above experiment it was revealed that different morphological characters like number of flowers plant ${ }^{-1}$, yield of flowers plant $^{-1}$, weight of petals plant ${ }^{-1}$ were maximum on the Seracole. Whereas, fresh weight of flower ${ }^{-1}$, diameter of fully opened flower were found to be maximum from Inca orange. In biochemical study suggests that $\mathrm{V}_{1}$ (Pusa Narangi gainda) have higher content of antioxidant. Due to the good source of antioxidant activity the different parts of the (Tagetes erecta L.) plants can be used as prevent progression of many diseases. Plant extracts will use to developed new drugs in pharmaceutical fields and in cosmetic world.

\section{References}

Ahluwalia, P., Kaur, A. and Dhillon, G.K. (2014). Effect of different drying methods on chemical and functional properties of marigold petals. International Journal of Food and Nutritional Sciences, 3: 54-59.

Anonymous. (2015). Indian Horticulture Data Base, National Horticulture Board, Gurgaon, pp. 165-167.

Bailey, C. A. and Chen, B. H. (1989). Chromatographic analyses of xanthophylls in egg yolks from laying 
hens fed turf Bermuda grass (Cynodon dactylon) meal. J Food Sci. 54: 584 586.

Bakar, A., Mohamed, M., Rahmat, A., and Fry, J. (2009). Phytochemicals and antioxidant activity of different parts of bambangan (Mangifera pajang) and tarap (Artocarpus odoratissimus). Food Chemistry 113: 479-483.

Beniwal, B.S. and Dahiya, S.S., (2012). Variability studies in marigold (Tagetes spp.). In: Abstracts of National Seminar on Sustainable Agriculture and Food Security: Challenges in Changing Climate, held at CCS Haryana Agricultural University, Hisar, Haryana, March 27-28, p. 298.

Bharathi, T. U. and Jawaharlal, M., (2014). Evaluation of African marigold (Tagetes erecta. L.) genotypes for growth and flower yield under Coimbatore condition. Tren. In. Biosci. 7(16): 2197-2201

Braca, A., Tommasi, N.D., Bari, L.D., Pizza, C., Politi, M. and Morelli, I. (2001). Antioxidant principles from Bauhinia terapotensis. J. Natl. Prod. 64: 892-895

Choudhary, M., Beniwal, B. S. and Kumari, A. (2014). Characterization of marigold genotypes using morphological characters. Res. On Crops. 15(4): 839845.

Deepa, V. P., Patil, V. S., Venugopal, C. K., Biradar, M. S. and Shridhar, K. (2016). Study on the growth and yield attributes of marigold (Tagetes spp.) hybrids under Dharwad condition. HortFlora Res. Spectrum, 5(1) 43-47.

Djeridane, A., Yousfi, M., Nadjemi, B., Boutassouna, D., Stocke, P. and Vidal, N. (2006). Antioxidant activity of some Algerian medicinal plants extracts containing phenolic compounds. Food Chemistry, 97: 654-660.

Gonzalez, M. E., Loarca-Pina, G. and RamosGomez, M. (1997). Antimutagenicity of xanthophylls present in aztec marigold (Tagetes erecta L.) against 1nitropyrene. Mutation Res. 389: 219226.

Hamburger, M., Adler, S., Baumann, D., Forg, A. and Weinreich, B. (2003). Preparative purification of the major anti-inflammatory triterpenoid esters from marigold (Calendula officinalis). Fitoterapia. 74: 328- 338.

Iftikhar, A., Muhammad, A., Atyab, A. and Ahmad, S. (2011). Fertilization enhances growth, yield, and xanthophyll contents of marigold. Turk Journal of Agriculture, 35: 641-648.

Jacobs, J.J.M.R., Engelberts, A., Croes, A.F. and Wullems, G.J. (1994). Thiophene synthesis and distribution in young developing plants of Tagetes patula and Tagetes erecta. J. Exp. Bot. 45: 14591466.

Naik, B. (2003). Stability analysis and standardization of production technology for flower and xanthophyll yield in marigold (Tagetes spp.). Ph.D. Thesis, University of Agricultural Sciences, Dharwad.

Narsude, P. B., Kadam, A. S. and Patil, V. K. (2010). Studies on the growth and quality attributes of African marigold (Tagetes erecta L.) genotypes under Marathwada condition. Asian. J. Hort. 5(2): 407- 410.

Piccagliy, R., Marotti, M. and Grandi, S. (1998). Lutein and lutein ester content in different types of Tagetes patula and T. erecta. Ind Crops Prod, 45-51

Poornachandragowda, G., R. Jayanthi and M. Jogi, (2016). Evaluation of African marigold (Tagetes erecta L.) genotypes for growth, yield and xanthophyll content. Environment and Ecology, 34 (2A): 807-810.

Ranganna, S. (1997). Hand book of Analysis and Quality control for fruit and vegetable Products (2nd ed.). New 
Delhi, India: Tata-Mc. Graw-Hill Publishing Company Ltd.

Rao, C.C., Goud, P.V., Reddy, K. M. and Padmaja, G. (2005). Screening of African marigold (Tagetes erecta L.) cultivars for flower yield and carotenoid pigments. Indian Journal of Horticulture, 3: 276-279.

Razzaq Owayez idan, V. M. Prasad and S. Saravanan. (2014). on Effect of organic manures on flower yield of African marigold (Tagetes erecta L.) cv. Pusa Narangi Gainda. International Journal of Agricultural Science and Research, (IJASR) 4: 39-50.

Srivastava, R.P. and Kumar, S. (2003) Fruits and vegetable preservation - principles and practices, International Book Distributing Co., India, pp. 360.

Usha bharathi, T., Jawaharlal, M., Kannan, M., Manivannan, N. and Raveendran, M. (2014) screening of African marigold (Tagetes erecta L.) For novelty The asian journal of horticulture 9: 492-495.

\section{How to cite this article:}

Amit Lohar, Jayoti majumder, Aritra Sarkar and Bishal Rai. 2018. Evaluation of African marigold (Tagetes erecta L.) Varieties for Morphological and Biochemical Characters under West Bengal Condition. Int.J.Curr.Microbiol.App.Sci. 7(10): 241-248. doi: https://doi.org/10.20546/ijcmas.2018.710.025 